XII. De sorore veteris Ade de Lond comprehensa past mortem secundum relscionem sntiquorum.

Memorandum quod predicta mulier in cimiterio de Ampilford sepeliebatur et infra breae post mortem comprehendebatur per Willelmum Trower seniorem et coniurata confitebatur se ipsam peragrare viam suam in nocte propter quasdam cartas quas tradidit iniuste Ade fratri suo. Hinc est quod olim quadam discordia otta inter maritum suum et ipsam, in preiudicium predicti viri sui et propriorum filiorum optulit fratri suo predictas cartas. ita quod post mortem suam frater squs expulsit maritum suum de domo sus, videlicet vno toft et crofte cum pertinenciis in Ampilford, et in Heslarton de vna bousta terre cum pertinenciis, per violenciam. Supplicabat igitur predicto Willelmo quod suggereret eidem fratri quod vellet redonare marito suo et filiis easdem cartas, et restituere illis terram suam. alioquin nullo modo posset in pace requiescere ante diem iudicii. Qui quidem Willelmus secundum iussionem suam suggessit predicto Ade. sed ille renuit cartas restituere, dicens non credo [...] hiis dictis. Cui ille. Verus est in omnibus sermo meus, vnde deo concedente sudietis sororem vestram vobis colloquentem de hac materis infa breue. Et altera nocte rarsus comprehendit illam ac attulit ad cameram prefati Ade, et loquebatur cum eo. Cui respondit induratus frater suus secundum quosdam. Si ambulaueris imperpetuum nolo predictas cartas redonsre. Cui respondit illa ingemiscens. Indicet deus inter me et te ob qusm causam. Sciss ergo quis vsque ad mortem tuam minime requiescam. vnde post mortem tuam tu peragrabis loco mei. Dicitur vlterius quod dextera manus illius pendebat iusum et erat valde nigra. Et interrogabatur qua de causa, respondebat quia sepius pugnando [?] extendit illam, iurando falsum. Tandem coniurate fuit ad alterum locam propter timorem nocturnum et terrorem gontis ville. Peto tamen veniam si forte offendi in scribendo contra veritatem. Dicitur tamen quod Adam [de lond above line] iunior vero heredi partim satisfecit post mortem Ade senioris.

\title{
The Mission of Cardinal Pole to Enforce the Bull of Deposition against Henry VIII
}

Cardinal Powr in his letter to Edward VI ${ }^{1}$ asserts that some ten years before, when he undertook his mission for the pope in 1539 to Charles $\nabla$ and Francis I, he had no intention of persuading them to make war against Henry VIII. He only advised; in case love and kindness failed, that threats should be used, and, as a last extreme remedy, that they should declare a commercial blockade. The eighth section of his Apologia, written not long before he was expecting to see the emperor, shows that his recollection was inacourate, for he there says his chief motive in the journey is to persuade the emperor to postpone the Turkish war and turn his arms against England. We know also that

\footnotetext{
1 Epistolarum Rog. Pali Collectio IV.
} 
Charles V reported to the Venetian ambassador after receiving Pole, 'On the one hand it seems that the cardinal wishes me to forbid trade with this King of England as a sort of warning, on the other he appears to want me to make war on him '.

The following unpublished letter of instruction to Pole may be used to check the two statements. PaUl van DYke.

Vatican, Varia Miscellanea, Armaria II. 49, fo. 6.

Primum benedicere S. Mti Nomine $\mathrm{S}^{\mathrm{ml}} \mathrm{D}$. et deinde exponere causas profectionis D. V. B. tum ad $\mathbf{M}^{\text {tom }}$ suam; tum ad Regem Christianissimum eas, quas a sus $\mathrm{S}$. habuit in mandatis super impietate et saevitis Regis Angliae.

Demum persuadere suae Mti. ut omni cura velit incumbere reductioni illius Regni ad veram religionem, nec ulterius pati regem illum impune saevire in Deum et in sanctos tam din a se et a toto Regno cultos. Ad quam rem habebit ducem authoritatem apcae. sedis quas ut monstraret viam in hac re, quam alii principes sequantur, publicavit bullam, habebit Regem Christianissimum, qui ultro so obtulit pro sua prudentia et pietate non deesse, habebit Regem Scotiae et huno novum creatum cardinalem Scotum, virum magni faciendum et multae authoritatis in illis partibus. Itaque prohibeantur comertia et si quid aliud videbitur ad hanc rem pertinere non omittatur : sicut pro sua prudentia D. V. B. melius et cogitabit et dicet.

Et quoniam expeditio, quae paratur in Turcos obstat plurimum huic Anglicae reductioni et concilio celebrando pro rebus fidei, et pro heresi Lutherana extirpanda D. V. B. conabitur omnibus viribus persuadere suse Mti.. longe praestare, ne praesens occasio restituendse religionis nostrae in pristinam formam amittatur, fieri a liga universa indutias et indūso etiam Christianissimo Regi cum Turcis ad aliquot tompus quod propter expeditionem in eosdem Turcas, quae non nisi diuturna et dubia et dispendiosa esse poterit, amittere et occasionem bene gerendae rei Anglicae et Lutheranae (capere) simulque ostendere suae Mti. id quod certissimum erit; ut si et bellum Turcarum prospere et ad votum prorsus cessisset, ne liga et sua $M$ tas. victrix posset $\theta$ victoria ulcisci hereticos et male de religione meritos, daturos interim eos ipsos operam, ut conspiratione facta Italiam invadant e pecunia Regis Angli qua is maxime abundat, et Germano milite, quo Lutherani pollent, provincias ob bellum Turcarum praesidio nudatas devastare ac diripere.

Et praeter haec, quaecumq. D. V. Bnae videbuntur ad hanc rem facere non tacebit.

Instructio pro Rmo Polo ad Caes. Maiestatem proficiente.

1 Armstrong, Charles V, ii. 21. 